\title{
PERANAN SELF REGULATION DI TENGAH KONSTELASI INDUSTRI MEDIA PADA HARIAN REPUBLIKA
}

\author{
Rizki Tania $^{1, \mathrm{a})}$, Dian Alfiah ${ }^{2}$, Lia Septiarini ${ }^{3}$, Irwasnyah Irwansyah ${ }^{4}$ \\ ${ }^{1}$ Program Magister Komunikasi Bisnis, Universitas Muhammadiyah Jakarta \\ ${ }^{2}$ Program Komunikasi Bisnis, Universitas Muhammadiyah Jakarta \\ ${ }^{3}$ Program Komunikasi Bisnis, Universitas Muhammadiyah Jakarta \\ ${ }^{4}$ Program Komunikasi Bisnis, Universitas Muhammadiyah Jakarta \\ a) $\ldots$
}

DOl:https://doi.org/10.18196/jkm.101005

Info artikel

Sejarah artikel :

Diterima 27 Jan 2018

Revisi 20 Mar 2018

Disetujui 20 Mar 2018

\begin{abstract}
Regulation and Journalistic Code of Ethic plays an important role as a guide for professional journalists. Similarly, self-regulation that plays an important role as Principles, Code of Ethics, and Standards of Conduct for the press and media companies. The purpose of this research is to prove the theoretical concept of communication technology and media regulation on the role of self regulation in the media industry constellation in Republika's Newspaper. This research is a descriptive qualitative research with research resource is Executive Editor of Republika's Newspaper. Data collection techniques used in this study are interview techniques, literature study and documentation. Regarding the concept of regulatory study theory in the form of self regulation in the constellation of the media industry in general, the press has a duty in maintaining professionalism and integrity by complying with applicable regulations without any conflict of interest from any party. In supporting media regulation at state law level, high commitment by media company in applying its self regulation is required. And accompanied by awareness and control of the public in supervising media behavior to stay professional.
\end{abstract}

Keyword : mass media, print media, media regulation, code of ethics, self regulation,journalistic code of ethic, self regulation, ethics of journalist behavior

\section{ABSTRAK}

Regulasi danKode Etik Jurnalistik memegang peranan penting sebagai pedoman jurnalis profesional. Begitu pula dengan self regulation yang memegang peranan penting sebagai Prinsip, Kode Etik, dan Standar Perilaku bagi insan pers serta perusahaan media. Tujuan dari penelitian ini adalah untuk membuktikan konsep teori mengenai teknologi komunikasi dan regulasi media terhadap peranan self regulation di tengah konstelasi industri media pada Harian Republika. Penelitian ini merupakan penelitian kualitatif deskriptif dengan narasumber penelitian adalah Redaktur Pelaksana Koran Harian Republika. Teknik pengumpulan data yang digunakan dalam penelitian ini adalah teknik wawancara, studi kepustakaan dan dokumentasi. Terkait konsep teori kajian regulasi dalam bentuk self regulation di tengah konstelasi industri media pada umumnya, insan pers memiliki tugas dalam menjaga profesionalitas dan integritasnya dengan mematuhi regulasi yang berlaku tanpa adanya konflik kepentingan dari pihak manapun. Dalam menunjang regulasi media pada level hukum negara, diperlukannya komitmen tinggi oleh Perusahaan media dalam menerapkan self regulation nya. Serta diiringi dengan kepedulian serta kontrol masyarakat dalam mengawasi perilaku media agar tetap profesional.

Kata kunci : media massa, media cetak, regulasi media, kode etik jurnalistik, self regulation, etika perilaku wartawan 


\section{PENDAHULUAN}

Media massa merupakan institusi yang berperan sebagai agent of changedan menjadi lembaga pelopor perubahan. Ini merupakan paradigma utama media massa(Mondry, 2009)Persaingan media massa pada era digital saat ini semakin ketat. Media cetak, elektronik, dan online saling menampilkan informasi teraktual dan mendalam untuk menarik perhatian publik. Akibatnya, muncul anggapan persaingan itu akan mematikan media cetak karena gencarnya pemberitaan media online dan elektronik.Namun hingga saat ini peran media cetak belum tergantikan karena kelebihannya dalam kedalaman dan ketajaman muatan atau konten berita.

Konstelasi industri media dewasa ini cukup unik, pasca tumbangnya pemerintahan Orde Baru, tantangan pers bukan lagi menghadapi rezim pemerintah, melainkan kepentingan pribadi ataupun kelompok,tantangan lainnya yaitu rendahnya tingkat kesejahteraan pekerja media atau wartawan, integritas insan pers, hingga regulasi media.

Pada kajian ini, kami mengidentifikasi masalah regulasi media yang difokuskan pada self regulation perusahaan media. Regulasi adalah instruksi resmi dan wajib adanya mengenai struktur (hubungan media dengan yang lain), perilaku atau konten media. Regulasi media dapat digambarkan dalam bentuk formal dan informal. Untuk tingkat formalitas, kekuasaan yang paling kuat berada di tangan pemerintah dan negara. Sedangkan untuk dimensi informal lebih mengandalkan kesepakan adat dan kepatuhan sukarela, namun ada tekanan untuk mematuhi aturan selain tekanan hukum seperti rekan, klien, penonton, dan sebagainya. Regulasi yang mengakomodir bagaimana pengisian konten yang tepat, menyesuaikan kebutuhan media dalam hal teknologi dan gempuran dunia ekonomi, menjaga kepentingan publik, serta mampu menguatkan independensi jurnalis demi profesionalitasnya. (Harmonis, 2018)

Regulasi yang mengatur media massa di Indonesia terdapat pada Undang-undang (UU) diantaranya yaitu (i) UU No. 33/2009 tentang Perfilman; (ii) UU No. 36/1999 tentang Telekomunikasi; (iii) UU No. 40/1999 tentang Pers; dan (iv) UU No. 32/2002 tentang Media Penyiaran. Disamping penggunaan regulasi tersebut, Mahkamah Agung (MA) mengeluarkan Surat Edaran Mahkamah Agung (SEMA) No. 13/2008 yang mengakui peran Dewan Pers secara formal dan menganjurkan seluruh hakim untuk meminta pendapat ahli dari dari Dewan Pers dalam setiap persidangan kasus yang berkaitan dengan pers.

Dewan Pers mengatur regulasi bagi insan pers dalam bentuk Kode Etik Jurnalistik. Kode etik merupakan acuan moral untuk mengatur perilaku seorang wartawan. Pelaksanaan kode etik jurnalistik dapat menjadi salah satu tolak ukur profesionalisme wartawan dalam melaksanakan tugas jurnalistiknya. Selain fungsinya sebagai media informasi, jurnalistik juga berfungsi mendidik, tulisan ataupun segala sesuatu yang dihasilkan oleh jurnalis tentu harus mengandung muatan edukasi.

Fokus penelitian diarahkan pada rumusan masalah sebagai berikut (i) bagaimana bentuk self regulation pada Harian Republika (ii) mengapa self regulation diterapkan pada Harian Republika(iii) bagaimana Self Regulation diterapkan pada Harian Republika (iv) bagaimana pengawasan self regulation pada Harian Republika. Seluruh elemen rumusan masalah diarahkan relevansinyakepada signifikansi persoalan-persoalan yang dihadapi danharus diatasi oleh industri media di Indonesia. Berdasarkan rumusan masalah tersebut, peneliti melakukan penelitian bertujuan untuk membuktikan konsep teori mengenai teknologi komunikasi dan regulasi media terhadap peranan self regulation di tengah konstelasi industri media pada Harian Republika. Serta manfaat yang diharapkan adalah dapat memberikan gambaran mengenai self regulasi di industri media.

\section{Tinjauan pustaka}

Sebagai referensi, peneliti meninjau penelitian sebelumnya dari beberapa peneliti lain. Pertama, referensi dari Erman Anom mengenai" Regulasi dan Kebijakan Media Cetak di Indonesia Masa Zaman Penjajah "(Anom, 2013)". Penelitian regulasi dan kebijakan Media Cetak Indonesia di zaman penjajah ini menelusuri atau menerka latar belakang dan coba memperlihatkan suasana pembangunan media di Indonesia. Tujuannya untuk melihat bagaimana persekitaran politik, ekonomi dan sosial budaya di Indonesia mempengaruhi arah perkembangan media. Objektif kajian ini adalah mengenai perkembangan media dalam era kerajaan kolonial Belanda, Jepun, era perjuangan kaum nasionalis. Dalam pendekatan penyelidikan kualitatif untuk penyelidikan ini, penulis menggunakan metode: Wawancara mendalam dan analisis dokumen. Dalam penelitian wawancara, pengkaji wawancara dilakukan dengan pimpinan redaksi dan pejabat Kementerian Penerangan Republik 
Indonesia dan tokoh-tokoh politik. Hasil penelitian didapatkan Pada asasnya yang dilakukan kerajaan penjajah terhadap pers nyatalah betapa kewenangan penguasa untuk memberikan dan menamatkan izin terbit pers merupakan salah satu ciri yang menonjol.

Kedua, referensi dari penelitian yang dilakukan oleh Budhi Widi Astuti yang berjudul "Self Regulation \& Persoalan Etika dalam Industri Penyiaran di Indonesia”.Tujuan penelitian ini untuk menegaskan pentingnya peraturan bagi penyiar radio, baik perundang-undangan maupun 'self regulation' dalam bentuk peraturan yang ditetapkan oleh Komisi Penyiaran Indonesia.Lebih dalam tentang pentingnya pemahaman dan menerapkan etika dalam kegiatan penyiaran radio.Penyiaran radio tidak hanya memiliki fungsi sebagai media informasi, pendidikan, hiburan yang sehat, kontrol dan kohesi sosial, tapi juga memiliki fungsi ekonomi dan budaya.Namun, bukan berarti menghilangkan salah satu dari fungsi atau dominasi satu fungsi saja. Dilema persaingan dalam siaran radio Industri tidak diharapkan membuat industri radio hanya menghasilkan konten siaran yang diminati hanya saja, tapi juga harus mengandung nilai etika. Dengan demikian, berdirinya penyiaran radio itu 'sehat' bukan hanya sekedar mimpi belaka.(Astuti, 2016)

Ketiga, referensi selanjutnya adalah dari Itsna Hidayatul Khusna dan Nuning Susilowati berjudul "Regulasi Media di Indonesia (Kajian pada Keterbukaan Informasi Publik dan Penyiaran)”. Penelitian ini bertujuan untuk mengetahui siapa yang membuat regulasi, fungsi dan pentingnya regulasi di media. Hasil penelitian menunjukkan bahwa regulasi sangat penting bagi keteraturan dan keseimbangan hubungan media dengan pemerintah, masyarakat, sesama industri media, dan global media. Regulasi media diperlukan untuk membatasi pemberitaan dan penggunaan teknologi media akan terjadinya celah pelanggaran hukum saat regulasi tersebut tidak dibuat. Regulasi dibentuk oleh lembaga legislatif dan eksekutif sedangkan pengujiannya dilakukan oleh lembaga yudikatif. (Khusna \& Susilowati, 2015)

Keempat, referensi dari Joko Tri Haryanto, pada penelitiannya yang berjudul "Etika Pemberitaan Politik Media Massa Tinjauan Etika Islam”. Penelitian ini mengungkap fenomena etika pemberitaan politik di media cetak nasional terkait dengan peristiwa politik, yaitu pergantian kepemimpinan nasional atau pilpres secara langsung tahun 2004, dan melihat etika pemberitaan tersebut dengan perspektif etika Islam. Penelitian ini ditujukan pada koran Kompas, Jawa Pos, Republika dan Media Indonesia yang terbit bulan September-Oktober 2004. Untuk itu maka penelitian ini menggunakan dua kerangka kerja, pertama, metode analisis wacana kritis yang menggunakan analisis Fairclough untuk mendapatkan gambaran yang utuh tentang "perilaku" media dalam konteks sosial politik; kedua, dengan metode penelitian filsafat untuk melakukan refleksi secara heuristik guna meninjau etika pemberitaan media cetak nasional tersebut dengan etika Islam. Perilaku media dalam pemberitaannya sangat dipengaruhi oleh berbagai faktor, baik dari internal media maupun eksternal media. Dalam tataran discoursepractise, meskipun media cetak mempertimbangkan perilaku khalayak, tetapi ideologi media massa dan kepentingan bisnis lebih mendominasi orientasi pemberitaannya. Sedangkan dalam tataran sosiocultural practise, pemberitaan media massa melakukan kompromi dan jalan tengah atas kepentingan ideologi media dengan kepentingan khalayak. Dengan demikian etika pemberitaan politik di media massa relatif belum dijalankan secara konsisten oleh pelaku media. (Haryanto, 2008).

Kelima, regulasi pernah diteliti oleh Muhammad Anshar Akil mengenai "Regulasi Media di Indonesia" (Tinjauan UU Pers dan UU Penyiaran)"(Akil, 2014). Media merupakan salah satu lembaga penting bangsa. Untuk melaksanakan peran dan fungsi media yang benar, media harus menerapkan peraturan secara profesional. Perilaku media tidak dapat dilepaskan dari kepentingan pihak-pihak yang terkait dengan sistem media. Secara umum, pers adalah seluruh industri media yang ada, baik cetak mau pun elektronik. Namun secara khusus, pengertian pers adalah media cetak (printed media). Dengan demikian, Undang-Undang Pers berlaku secara general untuk seluruh industri media, dan secara khusus untuk media cetak. Peraturan dapat menjadi hukum yang ditetapkan oleh pemerintah (seperti UU Pers); atau kode etik yang ditetapkan oleh wartawan atau organisasi profesi (seperti Kode Etik Jurnalistik). Peraturan pers di Indonesia diatur dalam Undang - Undang Nomor 40 Tahun 1999 tentang Pers. Untuk mendukung pelaksanaan UU Pers, Dewan Pers menetapkan Kode Etik Jurnalistik (KEJ). Sedangkan peraturan media penyiaran yang ditetapkan oleh Undang-Undang Nomor 32 Tahun 2002 tentang Penyiaran. Sebagai penjabaran dari UU Penyiaran, Komisi Penyiaran Indonesia (KPI) menetapkan Pedoman Perilaku Penyiaran (P3) sebagai proses batas pembuatan program siaran; dan Penyiaran Standar Program (SPS) sebagai batas program siaran dalam pengiriman. Besarnya harapan masyarakat terhadap peran media untuk ikut serta dalam mengatasi masalah-masalah bangsa. Perwujudan fungsi normatif media sangat ditentukan oleh 
profesionalisme media; sedangkan profesionalisme media dapat diketahui dari sejauh mana perilaku media menjunjung tinggi peraturan maupun kode etik media yang berlaku di Indonesia.

Terakhir, Penelitian yang dilakukan oleh Gabriel Gawi, Akhirul Aminulloh, dan Ellen Meianzi Yasak berjudul "Penerapan Kode Etik Jurnalistik dalam Surat Kabar Harian Surya Malang” pada tahun 2017. Tujuan dari penelitian ini adalah untuk mengetahui kode etik jurnalis dan faktor yang memengaruhi penerapan kode etik jurnalis dalam Surat Kabar Harian Surya Malang. Teknik pengumpulan data yang dilakukan adalah wawancara. Metode analisa data yang di gunakan yaitu metode deskriptif, dimana mendeskripsikan hasil data yang diperoleh. Hasil penelitian membuktikan bahwa penerapan kode etik jurnalis dalam Surat Kabar Harian Surya Malang sesuai pedoman UUD yang diterapkan di Indonesia untuk wartawan agar memberi berita atau informasi yang dipublikasikan bisa di pertanggung jawabkan. Dalam penerapan kode etik jurnalistik di Indonesia maka wartawan tidak membuat berita bohong, fitnah, sadis, dan cabul. Faktor penerapan kode etik jurnalis yaitu faktor kebijakan pemerintah dan hak asasi manusia untuk mendapatkan perlindungan dari berita yang salah. Kebijakan pemerintah terhadap ketaatan penerapan kode etik jurnalis yaitu agar berita yang dipublikasikan akurat, berimbang, sesuai fakta di lapangan untuk menghindari hal-hal yang dapat merugikan. (Gawi, Aminulloh, \& Yas, 2017)

Koran adalah medium massa utama bagi orang untuk memperoleh berita. (Vivian, 2015) koran adalah medium pilihan untuk lebih banyak iklan ketimbang media lainnya. (Vivian, 2015). Koran dan majalah pada zaman dahulu mengabaikan persolan etika dalam iklan palsu dengan berdalih bahwa halaman mereka terbuka untuk semua jenis iklan. Di bawah tekanan yang makin besar, publikasi melalui editorialnya kadang-kadang mengkritik iklan yang meragukan, tetapi tidak melarangnya. (Vivian, 2015)

Media cetak juga punya aturan industri yang beragam, semuanya tidak mengikat. Kebanyakan publikasi menolak iklan yang menyesatkan. Yang khas adalah Minot Daily News di North Dakota, yang menolak iklan untuk perdukunan, peramalan, penyembuhan magnetis, obat yang meragukan, dan iklan bohong. Banyak koran menolak iklan karena bertentangan dengan kebijakannya. Beberapa koran metropolitan menolak iklan film porno. (Vivian, 2015). Bentuk regulasi media di Indonesia (Harmonis, 2018)

1. On Regulation

Peraturan perundang-undangan yang dibuat bukan oleh media, yaitu oleh Pemerintah. Antara lain: UU Pers No.40/1999 tentang Kebebasan Pers, UU No.32/2002 tentang Penyiaran, PP No. 51 - 52/2005, UU ITE No.11/2008, dan lain-lain

2. Self Regulation

Peraturan perundang-undangan yang dibuat oleh media itu sendiri, seperti wartawannya atau manajemennya.

Etika media diperumit oleh standar kinerja yang berbeda-beda yang dibuat oleh media massa untuk diri mereka sendiri. Hal ini diperumit lagi oleh rentang ekspektasi dalam audiens massa. Satu ukuran tidak akan cocok untuk semua orang. (Vivian, 2015). Satu standar etika tidak mungkin berlaku untuk semua media massa. Etika media sebagian adalah fungsi dari apa yang dijanjikan media kepada audiensnya dan apa yang merupakan harapan audiensnya. Satu set aturan, yang mudah diingat dan dipakai tanpa banyak pemikiran, akan terlalu gampang. Tetapi etika tidak seperti itu. Etika membutuhkan proses intelektual dalam memilah-milah komitmen media, ekspektasi audiens, dan prinsip luas lainnya. Tetapi bahkan masih ada banyak lagi sekali prinsip-prinsip luas tersebut. (Vivian, 2015)

Ketika orang media massa mendiskusikan etika, mereka bicara tentang perilaku yang benar dan salah, tetapi menciptakan kebijakan etika bukan soal gampang. Banyak praktik media standar menekan garis antara benar dan salah, yang menyulitkan penetapan standar yang tegas yang bisa diaplikasikan dan diterima secara universal. Selain itu, banyak kode etik yang mengacaukan perbedaan antara perilaku tidak etis dengan perilaku yang mungkin kelihatan tidak etis tetapi sebenarnya etis. (Vivian, 2015)

Plagiarisme adalah menggunakan karya kreatif orang lain dengan diakui sebagai karya Anda, tanpa izin. Di antara faktor yang membuat jurnalis tidak nyaman ketika dihadapkan pada masalah plagiarisme adalah pertukaran berita yang diinstusionalisasikan, peran public relations dalam memunculkan berita, monitoring kompetisi, dan ingatan subliminal dan innocent recall.

Dalam (Littlejohn: 405) mengatakan, komunikasi massa merupakan proses organisasi media menciptakan dan menyebarkan pesan-pesan pada masyarakat luas dan proses pesan tersebut dicari, 
digunakan, dipahami, dan dipengaruhi oleh audiens. Salah satu model awal untuk menggambarkan pandangan ini adalah model yang digunakan oleh Harold Lasswell, yaitu:

Siapa, Mengatakan apa, Di saluran apa, Untuk siapa, Dengan pengaruh apa

Harold Lasswell dan Charles Wright merupakan sebagian dari pakar yang benar-benar serius mempertimbangkan fungsi dan peran media massa dalam masyarakat. Wright (1959) membagi media komunikasi berdasar sifat dasar pemirsa, sifat dasar pengalaman komunikasi dan sifat dasar pemberi informasi. Lasswell (1948/1960), pakar komunikasi dan profesor hukum di Yale, mencatat ada 3 fungsi media massa: pengamatan lingkungan, korelasi bagian-bagian dalam masyarakat untuk merespons lingkungan, dan penyampaian warisan masyarakat dari satu generasi ke generasi selanjutnya. Selain ketiga fungsi ini, Wright (1959,hlm.16) menambahkan fungsi keempat, yaitu hiburan. Selain fungsi, media juga mempunyai banyak disfungsi, yakni konsekuensi yang tidak diinginkan masyarakat atau anggota masyarakat. Suatu tindakan dapat memiliki baik fungsi maupun disfungsi. (Severin \& Tankard, 2005)

1. Pengawasan (Surveillance)

Pengawasan atau surveillance, fungsi pertama, memberi informasi dan menyediakan berita. Dalam membentuk fungsi ini, media sering kali memperingatkan kita akan bahaya yang terjadi seperti kondisi cuaca yang ekstrem atau berbahaya atau ancaman militer. Fungsi pengawasan juga termasuk berita yang tersedia di media yang penting dalam ekonomi, publik dan masyarakat, seperti laporan bursa pasar, lalu lintas, cuaca, dan sebagainya. Fungsi pengawasan juga bisa menyebabkan beberapa disfungsi. Kepanikan dapat saja terjadi karena ada penekanan yang berlebihan terhadap bahaya atau ancaman terhadap masyarakat.

Pada Kamis, 28 Oktober 2015, Harian Republika tampil dengan halaman yang berbeda. Hampir seluruh headline ditutupi kabut asap sehingga mengganggu tulisan berita. Tampilan yang menjadi pembicaraan di media social dan sempat menjadi trending topik di Twitter dengan tagar \#melawanasap dan \#republikasap itu rupanya sudah direncanakan benar oleh redaksi. Wakil Pemimpin Redaksi Harian Republika Irfan Junaidi menceritakan proses produksi koran yang terbit satu hari setelah Presiden Joko Widodo mengunjungi wilayah yang mengalami kebakaran hutan dan lahan tersebut. Irfan mengatakan, pemberitaan itu tidak lain demi tuntasnya kasus kebakaran hutan dan lahan di Sumatera dan Kalimantan. Namun, pemberitaan yang masif itu, menurut redaksi Republika, belum berbuah positif. Titik api baru malah terdeteksi di sejumlah wilayah. Redaksi pun lalu berfikir bagaimana terus mendorong agar persoalan segera selesai.(Kuwado, 2015)

2. Korelasi (Correlation)

Korelasi, fungsi yang kedua, adalah seleksi dan interpretasi informasi tentang lingkungan. Media sering kali memasukkan kritik dan cara bagaimana seseorang harus beraksi terhadap kejadian tertentu. Karena itu korelasi merupakan bagian media yang berisi editorial dan konsensus dengan mengekspos penyimpangan, memberikan status dengan cara menyoroti individu terpilih, dan dapat berfungsi untuk mengawasi pemerintah. Dalam menjalankan fungsi korelasi, media sering kali bisa menghalangi ancaman terhadap stabilitas sosial dan memonitor atau mengatur opini publik.

Fungsi korelasi dapat menjadi disfungsi ketika media terus-menerus melanggengkan stereotype dan menumbuhkan kesamaan, menghalangi perubahan sosial, dan inovasi, mengurangi kritik dan melindungi serta memperluas kekuasaan yang mungkin perlu diawasi.

Pada 2017, dalam rangka membantu meringankan penderitaan masyarakat Muslim etnis Rohingya di wilayah provinsi Rakhine, Myanmar, Republika membuka kesempatan bagi para pembaca yang ingin memberikan sumbangan kepada masyarakat Rohingya melalui Dompet Rohingya. Ini merupakan upaya nyata Republika dalam setiap tragedi kemanusiaan yang terjadi.(Republika, 2017)

3. Penyampaian Warisan Sosial (Transmission of the Social Heritage)

Penyampaian warisan sosial merupakan suatu fungsi di mana media menyampaikan informasi, nilai, dan norma dari satu generasi ke generasi berikutnya atau dari anggota masyarakat ke kaum pendatang. Dengan cara ini, mereka bertujuan untuk meningkatkan kesatuan masyarakat dengan cara memperluas dasar pengalaman umum mereka. Mereka membantu integrasi individu ke masyarakat dengan cara melanjutkan sosialisasi setelah pendidikan formal berakhir, ataupun dengan mengawalinya pada masa-masa pra-sekolah. Telah diakui bahwa media dapat mengurangi perasaan terasing (anomi) pada individu atau perasaan tak menentu melalui wadah masyarakat tempat dia dapat mengidentifikasikan dirinya.

Republika hingga saat ini berperan sebagai sarana untuk menyampaikan nilai dan warisan sosial budaya dari satu generasi ke generasi yang lain yakni nilai seperti ilmu pengetahuan mengenai agama 
Islam dan tradisi yang dilestarikan muslim di Indonesia seperti peringatan Maulid Nabi Muhammad, dan sebagainya.

\section{Hiburan (Entertainment)}

Sebagian besar isi media mungkin dimaksudkan sebagai hiburan, bahkan di surat kabar sekalipun, mengingat banyaknya kolom, fitur, dan bagian selingan. Media hiburan dimaksudkan untuk memberi waktu istirahat dari masalah setiap hari dan mengisi waktu luang. Media mengekspos budaya massa berupa seni dan musik pada berjuta-juta orang, dan sebagian orang merasa senang karena bisa meningkatkan rasa dan pilihan publik dalam seni.

Meski Republika kandungan kontennya lebih banyak memuat berita politik, media massa ini juga memiliki artikel hiburan seperti informasi kecantikan, tips kesehatan, tempat wisata, hingga olah raga yang dapat menghibur para pembacanya.

Tata kerja sistem pers terkait oleh "sejarah perkembangan media" di dalam masyarakatnya sendiri. Selain itu, didasari oleh pelbagai gagasan mengenai "institusi media" yang hendak dikenakan kepada pers ketika menjadi mediasi (penghubung) "masyarakat dengan peristiwa dunia", penghubung "penguasa dengan masyarakat", serta keperluan media mengembangkan "sistem sosial masyarakat industri/informasi. (Kurnia, Jurnalisme Investigasi, 2003)

Fred S. Siebert, Heodore Peterson, dan Wilbur Schramm menyebutkan empat macam teori pers yang berkembang saat itu, yaitu teori pers otoriter, teori pers libertarian, teori pers tanggung jawab sosial, dan teori pers komunis. (Haryanto, 2006)

\section{Pers Otoritarian}

Teori pers otoritarian berciri media sebagai alat propaganda pemerintah. Fungsi pers menjustifikasi kebenaran pendapat pemerintah terhadap berbagai persoalan yang muncul dalam kehidupan masyarakat. Pers boleh mengeluarkan kritik sejauh tidak bertentangan dengan status quo rezim yang berkuasa. Oritentasi perizinan media ada di tangan pemerintah sehingga izin dapat dicabut secara sepihak setiap saat dan sensor dilakukan secara ketat. (Masduki, 2007)

\section{Pers Komunis}

Teori pers komunis merupakan varian atau kelanjutan dari teori pers otoritarian. Menurut teori ini, media bersifat integral dengan partai politik atau pemerintah tidak diperkenankan adanya kepemilikan media secara pribadi. Media menyebarkan pandangan, terutama bersumber dari ucapan pejabat negara. (Masduki, 2007)

\section{Pers Liberal}

Teori pers liberal sebagai antitesis teori pers otoritarian memiliki ciri bahwa pers bukan alat pemerintah dan ia bisa dimiliki secara pribadi. Pers bebas dimiliki dan dioperasikan siapapun. (Masduki, 2007)

Tanggung Jawab Sosial

Teori tanggung jawab sosial, yang merupakan evolusi gagasan praktisi media, undang-undang media, dan hasil kerja Komisi Kebebasan Pers (Komisi Hutchin), berpendapat bahwa selain bertujuan untuk memberi informasi, menghibur, mencari untung (seperti halnya teori liberal), juga bertujuan untuk membawa konflik ke dalam arena diskusi (Siebert, Peterson, dan Schramm, 1950)

Prinsip penciptaan ruang publik menjadi dasar teori tanggung jawab sosial. Pers harus menjamin kesetaraan akses semua pihak untuk berbicara lewat media, sebab kontrol media diletakkan pada opini masyarakat, yakni preferensi konsumen, dan standar profesional. Untuk menjamin kepentingan umum, dimungkinkan adanya intervensi negara secara terbatas. Dalam teori tanggung jawab sosial, dikenal adanya bahan independen yang akan memantau dan menilai fungsi sosial pers. (Masduki, 2007)

\section{Sistem Pers di Indonesia}

Sistem pers di Indonesia dapat dikatakan sebagai sistem Pers Kontinum atau mengarah. Hal tersebut terlihat pada masa Orde Baru, bisa dinilai, pers Indonesia bekerja atas dasar sistem yang menyerap pelbagai teori sistem pers. Pemerintah Orde Baru sering menyatakan Pers Indonesia adalah pers yang bertanggung jawab. Pers dituntut bertanggung jawab kepada pemerintah atas segala apa yang dilakukan dan disampaikannya. Kemudian dipraktekkan pula Teori Media Pembangunan, dimana Pers wajib mengikuti unsur pemberlakuan orientasi pembangunan ekonomi, politik, dan sosial.(Kurnia, Jurnalisme Kontemporer Edisi Kedua, 2017)

Selanjutnya adalah Pers Pancasila yaitu sistem pers yang berlaku di Indonesia. Pers Pancasila adalah Pers Pembangunan " (Wahyudi: 1991). Ideologi Pancasila dipakai sebagai asas sistem pers. Pers bertugas memberikan informasi pembangunan, memotivasi masyarakat agar menerima ide-ide pembangunan. Bahkan diterapkan pula sistem otorianisme, yang terindikasi dengan fenomena aturan 
perijinan yang diberlakukan (Kurnia, Jurnalisme Kontemporer Edisi Kedua, 2017) Namun pada kenyataannya pada masa Orde Baru hanya pemberitaan yang terkait dengan Pemerintah yang dikawal oleh Pemerintah pada masa itu.

Pasca runtuhnya orde baru, pers pun mulai bebas bergerak. Pergantian rezim orde baru ke reformasi pun membawa warna baru. Profesionalisme menjadi acuan. Di awal zaman inikemudian lahirlah regulasi baru di bidang persyaitu ditandai lahirnya Undang-Undang No.40tahun 1999 tentang Pers, berlaku hingga sekarang.Kebebasan pers dalam undang-undangtersebut ditemui di Bab II Pasal, 3 sampai denganPasal 6 dan Bab III Pasal 7 dan 8, serta Bab IVPasal 9 s/d Pasal 14.(Martono, 2014)

Agenda Setting

Agenda setting diciptakan oleh Maxwell McCombs dan Donald Shaw (1972, 1993), dua peneliti dari Universitas North Carolina, untuk menjelaskan gejala atau fenomena kegiatan kampanye pemilihan umum (pemilu) yang telah lama diamati dan diteliti oleh kedua sarjana tersebut. Penelitian oleh Mc Combs dan Shaw merupakan tonggak awal perkembangan teori agenda-setting. Dalam hal ini, McCombs dan Shaw tidak menyatakan bahwa media secara sengaja berupaya memengaruhi publik, tetapi publik melihat kepada para profesional yang bekerja pada media massa untuk meminta petunjuk kepada media ke mana publik harus memfokuskan perhatiannya. (Morissan, 2013)

Stephen Reese (1991) menyatakan, bahwa agenda media merupakan hasil tekanan (pressure) yang berasal dari luar dan dari dalam media itu sendiri. (Reese S. D., 1991)

Dengan kata lain, agenda media sebenarnya terbentuk berdasarkan komunikasi sejumlah faktor yang memberikan tekanan kepada media seperti proses penentuan program internal, keputusan redaksi dan manajemen serta berbagai pengaruh eksternal yang berasal dari sumber nonmedia seperti pengaruh individu tertentu, pengaruh pejabat pemerintahan, pemasang iklan, dan sponsor. (Morissan, 2013)

(Littlejohn \& Foss, 2005) Dalam hal ini terdapat empat tipe hubungan kekuasaan antara media massa dengan sumber-sumber kekuasaan di luar media, khususnya pemerintah/penguasa, yaitu:

5. High-power source, high-power media, yaitu sumber kekuasaan luar besar, kekuasaan media besar.

6. High-power source, low-power media, yaitu sumber kekuassan luar besar dengan kekuasaan media kecil.

7. Lower-power source, high-power media, yaitu hubungan antara sumber kekuasaan luar kecil dengan kekuasaan media besar.

8. Low-power source, low-power media, yaitu sumber kekuasaan luar kecil dengan kekuasaan media kecil.

Dalam tipe hubungan keempat ini, agenda publik akan ditentukan oleh peristiwa itu sendiri dan bukan ditentukan oleh media atau para pemimpin politik.

Hirarki Pengaruh

Teori yang dikembangkan oleh Pamela J. Shoemaker dan Stephen D. Reese ini berbicara tentang bagaimana pengaruh internal dan eksternal sebuah organisasi media memengaruhi pemberitaan sebuah media. Pada teori hirarki pengaruh terdapat beberapa tingkatan atau level yaitu level individu, level rutinitas media, level organisasi media, dan level ideologi. Diantara kelima level tersebut memiliki keterkaitan satu sama lain. (Shoemaker \& Reese, 1996)

Asumsi dari teori ini adalah bagaimana isi pesan media yang disampaikan kepada khalayak adalah hasil pengaruh dari kebijakan internal organisasi media dan pengaruh dari eksternal media itu sendiri. Pengaruh internal pada konten media sebenarnya berhubungan dengan kepentingan dari pemilik media, individu wartawan sebagai pencari berita, rutinitas organisasi media. Sedangkan faktor eksternal yang berpengaruh pada konten media berhubungan dengan para pengiklan, pemerintah masyarakat dan faktor eksternal lainnya. Stephen D. Reese mengemukakan bahwa isi pesan media atau agenda media merupakan hasil tekanan yang berasal dari dalam dan luar organisasi media. (Reese S. D., 1991)

Teori hirakri pengaruh media pada level organisasi media membahas seberapa kuat pengaruh organisasi pada sebuah pemberitaan. Level organisasi ini berkaitan dengan struktur manajemen organisasi pada sebuah media, kebijakan sebuah media, dan tujuan sebuah media. Penentu kebijakan pada sebuah media dalam menentukan sebuah pemberitaan tetap dipegang oleh pemilik media. Ketika tekanan datang untuk mendorong, pekerja secara individu dan rutinitas mereka harus tunduk pada organisasi yang lebih besar dan tujuannya. (Shoemaker \& Reese, 1996); 


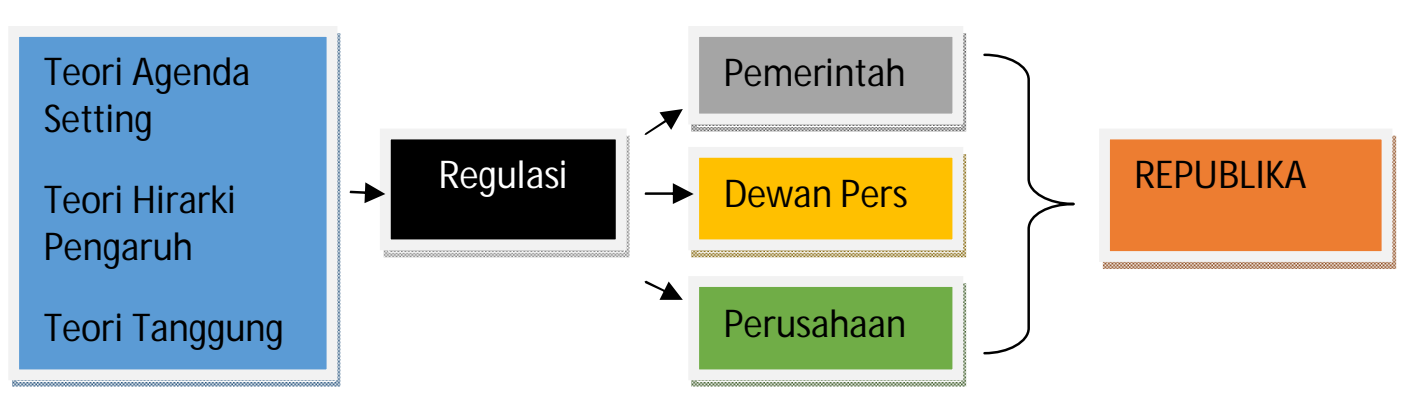

Gambar 1. Kerangka Konseptual

\section{METODE PENELITIAN}

Penelitian yang dilakukan merupakan penelitian kualitatif deskriptif dengan narasumber penelitian adalah Redaktur Pelaksana Koran Harian Republika yang bertujuan menjelaskan fenomena dengan sedalam-dalamnya melalui pengumpulan data kemudian dideskripsikan secara konkret terkait peranan Self Regulation di tengah konstelasi industri media pada Harian Republika.Teknik pengumpulan data yang digunakan dalam penelitian ini adalah teknik wawancara, studi kepustakaan dan dokumentasi.Teknik wawancara digunakan untuk mendapatkan data yang akurat tentang self regulation di Harian Republika.Teknik studi kepustakaan dan dokumentasi untuk mendapatkan data pedoman tertulis dari self regulation di Harian Republika.Data yang sudah didapat dari wawancara, studi kepustakaan dan dokumentasi, kemudian dirangkum dan diseleksi.Merangkum dan menyeleksi data didasarkan pada pokok permasalahan yang telah ditetapkan dan dirumuskan.Untuk menganalisis data yang diperoleh melalui wawancara, studi kepustakaan, dan observasi digunakan metode analisis deskriptif dengan tujuan untuk mengetahui bagaimana self regulation yang diterapkan di Harian Republika.Selanjutnya hasil penelitian diklarifikasi dan disajikan.

\section{PEMBAHASAN}

\section{Self Regulation dan Perananannya pada Konstelasi Industri Media}

Setiap media massa di Indonesia harus berlandaskan pada Regulasi Media di Indonesia seperti Undang-undang Pers dan Kode Etik Jurnalistik. Menurut Dewan Pers, untuk menjamin kemerdekaan pers dan memenuhi hak publik untuk memperoleh informasi yang benar, wartawan Indonesia memerlukan landasan moral dan etika profesi sebagai pedoman operasional dalam menjaga kepercayaan publik dan menegakkan integritas serta profesionalisme (Dewan Pers, 2011)

Self Regulation merupakan aturan khusus yang diterapkan oleh masing-masing Perusahaan.Self-regulation dapat diartikan sebagai tanggung jawab yang diberikan kepada pelaku media untuk menerapkan sendiri regulasi yang mereka pilih. Pelaku media ini kemudian akan diawasi dari dalam maupun oleh organisasi media itu sendiri atau oleh badan publik. Peranan self regulation dalam media lebih kepada kode praktik jurnalistik untuk kepentingan akurasi dan keadilan serta prosedur pelaksanaan (Harmonis, 2018)

Kode Etik Jurnalistik merupakan aturan mengenai perilaku dan pertimbangan moral yang harus dianut dan ditaati oleh media pers dalam siarannya (Masduki, 2014).

Pelaksanaan Kode Etik Jurnalistik juga merupakan perintah dari Undang-Undang Pasal 7 ayat 2 undang-undang No. 40 Tahun 1999 tentang pers yang berbunyi "Wartawan memiliki dan menaati kode etik jurnalistik". Ini berarti, wartawan yang melanggar kode etik jurnalistik sekaligus juga melanggar undang-undang. Wartawan dalam kegiatan jurnalistiknya meliputi mencari, memperoleh, memiliki, menyimpan, mengolah dan menyampaikan informasi baik dalam bentuk tulisan, suara (audio), gambar (visual), suara dan gambar (audio visual), serta data dan grafik maupun dalam bentuk lainnya dengan menggunakan media cetak, media elektronik, dan segala jenis saluran yang tersedia dan tetap dalam pengawasan badan yang terkait kegiatan pers Indonesia (Gawi, Aminulloh, \& Yasak, 2017) 
Kode Etik Pers Nasional yang profesional dapat berupa self regulation yang dibakukan menjadi peraturan pada sebuah perusahaan media yang menaungi insan pers, seperti code of ethics, code of practice, dan professionalism standard.Tujuannya adalah meregulasi diri sendiri pada khususnya dan perusahaan media pada umumnya sehingga tidak merugikan kepentingan publik.

Peran Self Regulation itu sendiri tidak jauh berbeda dengan regulasi media pada umumnya yaitu sebagai pedoman operasional dalam menjaga kepercayaan publik dan menegakkan integritas serta profesionalisme. Menurut Baran (Baran, 2014), persoalan-persoalan pada media yang biasanya muncul terutama adalah konflik kepentingan menyangkut :

9. Apakah media mampu menyampaikan kebenaran dan kejujuran secara utuh mengingat media melakukan framing terhadap isu tertentu.

10. Penghormatan terhadap privasi baik bagi figur publik maupun orang-orang biasa yang menjadi tokoh berita

11. Kerahasiaan nara sumber karena alasan keamanan

12. Konflik kepentingan antara pribadi media dan kepentingan publik

13. Konflik antara keharusan mencari keuntungan sebagai sebuah perusahaan dan tanggung jawab sosial

14. Etika tentang konten yang ofensif

Tantangan di negara berkembang seperti Indonesia, sejarah telah membuktikan betapa ketimpangan arus informasi berkaitan dengan persoalan demokrasi, terutama soal kontrol terhadap jalannya kekuasaan serta partisipasi masyarakat dalam proses politik (Birowo, 2004) Konstelasi industri media di Indonesia tak terelakkan oleh adanya konflik kepentingan antara pribadi media dan kepentingan publik, konflik antara keharusan mencari keuntungan sebagai sebuah perusahaan dan tanggung jawab sosial, serta keraguan media mampu menyampaikan kebenaran dan kejujuran secara utuh mengingat media melakukan framing terhadap isu tertentu.

Pada penelitian sebelumnya, "Regulasi dan Kebijakan Media Cetak di Indonesia Masa Zaman Penjajah" (Anom, 2013) dimana penelitian tersebut menjadi landasan perkembangan regulasi media dewasa ini dan mendukung penelitian kami. Kemudian pada penelitian Budhi Widi Astuti yang berjudul "Self Regulation \& Persoalan Etika dalam Industri Penyiaran di Indonesia" dan Itsna Hidayatul Khusna dan Nuning Susilowati berjudul "Regulasi Media di Indonesia (Kajian pada Keterbukaan Informasi Publik dan Penyiaran)" bahwa penelitian ini mendukung penelitian sebelumnya yaitu mengenai konten media yang harus mengandung etika dan berpedoman pada regulasi dan self regulation perusahaan media. Sedangkan pada penelitian Joko Tri Haryanto yang berjudul "Etika Pemberitaan Politik Media Massa Tinjauan Etika Islam" membuktikan bahwa etika pemberitaan politik di media massa relatif belum dijalankan secara konsisten oleh pelaku media, apabila dilihat dalam konteks konstelasi industri media dapat dikatakan etika media massa belum dijalankan secara konsisten oleh pelaku media, namun bagi Self Regulation di Harian Republika, hal tersebut ditolak sebab dapat dikatakan self regulation yang dimiliki Republika cukup ketat dibandingkan regulasi yang sudah ada sebelumnya melalui Undang-undang. Selanjutnya penelitian Muhammad Anshar Akil mengenai "Regulasi Media di Indonesia" (Tinjauan UU Pers dan UU Penyiaran) mendukung penelitian kami sebab secara general mendeskripsikan bagaimana regulasi media yang ada di Indonesia. Terakhir adalah penelitian Gabriel Gawi, Akhirul Aminulloh, dan Ellen Meianzi Yasak berjudul "Penerapan Kode Etik Jurnalistik dalam Surat Kabar Harian Surya Malang" pada penelitian ini membuktikan faktor yang memengaruhi penerapan kode etik jurnalis pada Surat Kabar Harian Surya Malang dan penelitian tersebut relatif tidak berbeda dengan penelitian kami.

\section{Self Regulation di Harian Republika}

Sebagai salah satu media nasional, Harian Republika memiliki peranan penting dalam menyebarkan informasi yang akurat, berkualitas, dan bermanfaat bagi masyarakat sesuai dengan slogan Perusahaan yaitu "Mencerdaskan Kehidupan Bangsa".Harian Republika dalam setiap kegiatan kejurnalistikannya berpegang teguh pada aturan-aturan yang berlaku, namun demi tercapainya visi dan misi Harian Republika dibentuklah Self Regulation yang mengatur perilaku insan wartawan Republika.

Penerapan kode etik jurnalistik di Harian Republika saat ini sudah sesuai dengan pedoman Undang-Undang Dasar (UUD) yang diterapkan di Indonesia. Secara garis besar kode etiknya 
samanamun Harian Republika memiliki Self Regulation dalam bentuk buku kode etik wartawan. Di dalam buku kode etik wartawan tersebut, Harian Republika berusaha untuk menempatkan diri sebagai media netral sehingga kode etik jurnalistik yang dibuat lebih mengatur kepada sanksi hukum atas pelanggaran yang dibuat oleh jurnalis.

Selain itu, Harian Republika membentuk Self Regulation adalah sebagai penerapan isi piagam Palembang yang dibuat pada pertemuan Hari Pers Nasional 2010 di Palembang, Sumatera Selatan. Self Regulation ini merupakan rancangan prinsip, kode etik, dan standar perilaku insan Republika yang terangkum dalam buku Prinsip, Kode Etik, dan Standar Perilaku Republika yang dirancang pada Rapat Kerja Tahunan Redaksi Republika, 5 - 7 Oktober 2012. Selain itu, pasal-pasal pada Prinsip, Kode Etik, dan Standar Perilaku Republika juga mengacu atau berlandaskan pada regulasi-regulasi yang dibuat oleh Pemerintah.

Tujuan dibentuknya Prinsip, Kode Etik, dan Standar Perilaku Republika adalah sebagai pegangan insan wartawan Republika agar selalu menjaga profesionalitas serta kredibilitas profesinya dan perusahaan pers. Prinsip, Kode Etik, dan Standar Perilaku Republika ini tak serta-merta hanya sebagai formalitas saja namun juga pelaksanaannya diawasi oleh lembaga ombudsman sebagai pihak independen atau diluar Harian Republika serta Dewan Kehormatan Wartawan Republika yaitu para wartawan Republika yang ditunjuk dan diangkat langsung oleh Pemimpin Redaksi sebagai lembaga peradilan bagi pelanggar Prinsip, Kode Etik, dan Standar Perilaku Republika.

Pada Harian Republika memiliki tingkatan wartawan pada jajaran redaksionalnya. Istilah bagi wartawan yang baru bergabung adalah Calon Reporter atau carep. Para carep Harian Republika memiliki masa orientasi atau pengenalan selama satu tahun sebelum diangkat sebagai wartawan Harian Republika. Pada masa itu akan ada penilaian, diantaranya carep harus mengerti positioning Republika pada industri media serta nilai-nilai serta Prinsip, Kode Etik, dan Standar Perilaku Republika. Setelah masa orientasi tersebut dilanjutkan pelatihan secara umum, satu orang wartawan akan didampingi oleh satu orang mentor.Pada masa pengenalan tersebut, diharapkan wartawan belajar memahami Prinsip, Kode Etik, dan Standar Perilaku Republika serta nilai-nilai yang berlaku di Harian Republika.

Berdasarkan Prinsip, Kode Etik, dan Standar Perilaku Republika terdapat tiga jenis kategori sanksi bagi pelanggarnya, yaitu kategori ringan, sedang, dan berat. Sebagai contoh, ada kasus plagiarisme oleh calon reporter, berita hoax, serta gratifikasi.Plagiarisme menjadi salah satu poin penting dalam Prinsip, Kode Etik, dan Standar Perilaku Republika karena telah menodai integritas wartawan. Tindakan yang diambil oleh Republika adalah memecat calon reporter tersebut karena telah melanggar self regulation yang ditetapkan oleh Harian Republika serta dikhawatirkan perbuatan tersebut akan terulang kembali apabila tidak ada sanksi tegas dengan efek jera. Untuk berita hoax, prosedur yang dijalankan oleh Republika adalah dengan memanggil wartawan yang menuliskan berita tersebut untuk dimintai pertanggungjawabannya oleh kepala newsroom, redaktur terkait, dan pihak lain. Wartawan tersebut harus menyertakan hasil rekaman wawancara sebagai bukti kebenaran dari berita yang ditulisnya, sebab kasus berita hoax dapat merugikan masyarakat dan Perusahaan pada khususnya. Mengenai Begitu pula dengan gratifikasi, wartawan Harian Republika dilarang keras menerima gratifikasi dalam bentuk apapun untuk menghindari konflik kepentingan.

Pada teori hirarki pengaruh, dimana pemberitaan media dipengaruhi oleh faktor internal dan eksternal sebuah organisasi media, mengasumsikan bagaimana isi pesan media yang disampaikan kepada khalayak adalah hasil pengaruh dari kebijakan internal dan eksternal organiasi media sehingga bila dikaitkan dengan regulasi media maka isi pesan media adalah untuk kepentingan publik. Hal tersebut dapat terbukti pada self regulation harian Republika, dimana Prinsip, Kode Etik, dan Standar Perilaku Republika dijunjung tinggi demi terjaganya profesionalitas dan integritas wartawan serta Perusahaan.

\section{KESIMPULAN}

Media massa termasuk media cetak merupakan pilar penting bagi demokrasi. Maka fungsi normatif pers adalah memberi informasi dan pendidikan sekaligus kontrol sosial bagi masyarakat serta pemerintah. Hal tersebut dapat diwujudkan manakala media massa melakukan aktivitasnya disertai dengan rasa tanggung jawab, penuh etika, dan sesuai dengan regulasi yang berlaku. 
Terkait konsep teori kajian regulasi dalam bentuk self regulation di tengah konstelasi industri media pada umumnya, insan pers memiliki tugas dalam menjaga profesionalitas dan integritasnya dengan mematuhi regulasi yang berlaku tanpa adanya konflik kepentingan dari pihak manapun. Disamping itu, antara on regulation atau regulasi yang dibuat oleh Pemerintah dan self regulation yang dibuat oleh Perusahaan media dapat seiring sejalan (paralel) serta saling melengkapi.

Media massa yang besar sudah semestinya memiliki standar perilaku sebagai perwujudan nilai profesionalisme dan integritas jurnalistiknya. Namun sering kali munculnya faktor konflik kepentingan sehingga menjadikan nilai profesionalisme dan integritas jurnalistik terlupakan. Untuk itu, dalam membangun etika profesional insan pers dapat dilakukan pada level normatif yang berupa peraturan yang sifatnya pemaksaan, perintah, serta larangan yang terikat dalam ranah hukum sehingga memaksa insan pers untuk menaati etika dan peraturan tersebut di dalam pemberitaannya.

Maka dari itu, dalam menunjang regulasi media pada level hukum negara, diperlukannya komitmen tinggi oleh Perusahaan media dalam menerapkan self regulation nya. Serta diiringi dengan kepedulian serta kontrol masyarakat dalam mengawasi perilaku media agar tetap profesional.

\section{DAFTAR PUSTAKA}

Abrar, A. N. (2008). Kebijakan Media Interaktif: Belum Melancarkan Sistem Komunikasi Indonesia. Jurnal Ilmu Komunikasi Vol 5, No. 1, 87 - 98.

Akil, M. A. (2014). Regulasi Media di Indonesia. Jurnal Dakwah Tabligh, 137-145.

Anom, E. (2013). Regulasi dan Kebijakan Media Cetak di Indoensia Masa Zaman Penjajahan. Jurnal Komunikologi Volume 10 Nomor 2, 73.

Astuti, B. W. (2016). Regulation \& Persoalan Etika dalam Industri Penyiaran di Indonesia (Mendambakan Penyiaran Radio yang Beretika).

Baran, S. J. (2014). Introduction to Mass Communication, Media Literacy and Culture. McGraw Hill Companies.

Dewan Pers. (2011, Juli 28). Peraturan: Dewan Pers. Retrieved from Dewan Pers Web site: http://dewanpers.or.id/peraturan/detail/190/kode-etik-jurnalistik

Gawi, G., Aminulloh, A., \& Yas, E. M. (2017). Penerapan Kode Etik Jurnalistik Dalam Surat Kabar Harian Surya Malang. Fakultas Ilmu Sosial dan Ilmu Politik.

Harmonis, D. F. (2018, Januari 1). Bentuk Regulasi Media. Summary Notes-1708-TKRM-10-02. Jakarta, Jakarta, Indonesia: HarukaEdu.com.

Haryanto, I. (2006). Indonesia Diberendel. Yogyakarta: LKIS.

Haryanto, J. T. (2008). Etika Pemberitaan Politik dalam Media Massa Tinjauan Etika Islam (Studi Analisis Berita Pergantian Kepemimpinan Nasional Bulan September-Oktober 2004 di Media Cetak Nasional . Semarang: IAIN Walisongo.

Khusna, I. H., \& Susilowati, N. (2015). Regulasi Media di Indonesia (Kajian pada Keterbukaan Informasi Publik dan Penyiaran). Promedia, 92-104.

Kuwado, F. J. (2015, Oktober 10). www.nasional.kompas.com. Retrieved November 6, 2017, from www.Kompas.com: http://nasional.kompas.com/read/2015/10/10/14411461/Ini.Cerita.Redaksi.Republika.di.Bali k.Koran.Asap.

Kurnia, S. S. (2003). Jurnalisme Investigasi. Jakarta: Yayasan Pustaka Obor.

Kurnia, S. S. (2017). Jurnalisme Kontemporer Edisi Kedua. Jakarta: Yayasan Pustaka Obor Indonesia.

Littlejohn, S. W., \& Foss, K. A. (2005). Theories of Human Communication. New Mexico: Wadswo rth Publishing Company.

Martono, J. (2014). Kebebasan Pers di Indonesia Pada Era Reformasi dan Ekonomi Politik Media. Insani Vol. 1 No. 1, 11 - 20.

Masduki. (2007). Regulasi Penyiaran: Dari Otoriter ke Liberal. LKIS.

Mondry. (2009). Pemahaman Teori dan Praktek Jurnalistik. Bogor: Ghalia Indonesia.

Morissan. (2013). Teori Komunikasi Individu Hingga Massa. Jakarta: Prenadamedia Group. 
Rakhmat, J. (2014). Psikologi Komunikasi. Bandung: Remaja Rosdakarya.

Reese, S. D. (1991). In Setting the media's Agenda: A Power Ballance Perspective. Beverly Hills: Sage.

Reese, S. D. (1991). Setting the Media's Agenda: A Power Balance Perspective.

Republika. (2017, September 4). Peduli Rohingya, Republika Buka Layanan Donasi. Retrieved Januari 24, 2018, from Republika.co.id: http://nasional.republika.co.id/berita/nasional/umum/17/09/04/ovpu0u354-peduli-rohingyarepublika-buka-layanan-donasi

Severin, W. J., \& Tankard, J. W. (2005). Teori Komunikasi (Sejarah, Metode, dan Terapan di Dalam Media Massa). Jakarta: Kencana Prenadamedia Group.

Shoemaker, P. J., \& Reese, S. D. (1996). In Mediating The Message. New York: Longman Publisher.

Sufyan, M. (2017, Juli 7). News Nasional: Kompas.com. Retrieved from Kompas.com: http://nasional.kompas.com/read/2017/07/07/18590671/berapa.lama.lagi.usia.koran.di.indone sia.

Vivian, J. (2015). Teori Komunikasi Massa. Jakarta: Prenadamedia Group. 